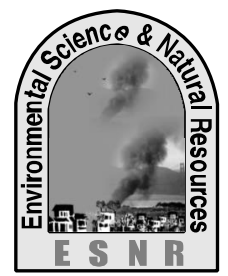

\title{
Gender Participation on Rice Post-harvest Activities in Bangladesh
}

\author{
M. Jahan* and J. R. Sarker
}

Department of Agricultural Economics

Bangabandhu Sheikh Mujibur Rahman Agricultural University, Salna, Gazipur-1706

*Corresponding author: mjahan.aec@bsmrau.edu.bd

\begin{abstract}
The study was undertaken to examine the extent of women along with men participated in post-harvest activities; to identify the problems and constraints faced by them and find suitable solution from their perception. The post-harvest activities were estimated at farm level in Aman rice at Rangpur, Nilphamari, Khulna, Satkhira and Jessore district of Bangladesh by using survey data collected randomly from 270 rice growing households for the year 2012-13. It employed participatory approaches to investigate farmersôperceptions on post-harvest management. The analyses shows women spends more time (591 hours $\left.\mathrm{ha}^{-1}\right)$ on PH activities than men $\left(581\right.$ hours $\left.\mathrm{ha}^{-1}\right)$ but the ultimate decision maker of those activities are male indicating that women are very seldom given the opportunities to implement their ideas for execution although they are now gaining the right to give their opinion because of social awareness.
\end{abstract}

Key words: Decision making ability, Post-harvest activities, Post-harvest loss, Women

\section{Introduction}

In Bangladesh though most of the farmers are male but a lot of women are now playing an important role in the improvement of agricultural sector as well as the economy of Bangladesh. Being a traditional Muslim society, women hardly participate in agricultural activities outside home (Hossain and Bayes, 2009). Womenôs agricultural activities were confined to homestead production and post-harvest operations, however, in recent years they are mostly involved in livestock and poultry rearing activities along with men besides crop production activities. Official statistics often underestimate the value of womenôs work and their overall contribution to national wealth. Women continue to provide a large proportion of the labor that goes into agriculture. Among the neighboring countries, only 59 per cent of Bangladeshi women, as compared to over 74 per cent of Indian, 64 per cent Pakistani and 85 per cent Nepali women, are employed in agriculture (Hossain and Jaim, 2011). Indeed, in most Asian countries the number of women employed in agriculture as a percentage of the economically active population is higher than that of men. However, women's contribution to agriculture, which is considered as unpaid family labor, is grossly underestimated. In fact, if unpaid work were included, the figures for female employment in agriculture would be even higher (FAO, 2003). The roles that women play in agriculture vary from region to region and country to country.

Women in Bangladesh are involved in more than half of all post-harvest processing activities. At the household level, they are almost entirely responsible for tasks such as par boiling, drying and storing seed for planting the following season and storing grain for household use or sale later. Keeping the above views in mind the research work was undertaken with following objectives are investigate the extent of women involvement at all the level in post-harvest activities of rice and to identify the major problems and constraints faced by the farmers, especially women and to suggest policy implications for reducing losses as well as increasing farm productivity.

\section{Materials and Methods}

In order to estimate the trends of female labor participation at the national level, data from Labor Force Surveys (LFS) conducted by the Bangladesh Bureau of Statistics (BBS) in 1995-96, 1999-2000, 2002- 2003 , 2005-2006 and 2010 were used. The post-harvest activities were observed at farm level in Aman rice by using survey data, collected randomly from 270 rice growing households for the year 2012-13. A participatory methodology was followed, to elicit information about post-harvest processes followed in the research Areas (Rangpur, Nilphamari, Satkhira, Khulna and Jessore). The method named Key Informants Interview (KII) was followed for the survey of post-harvest activities and constraints faced by women along with men. Purposive sampling procedure was followed to select the respondents of the research locations.

\section{Analytical technique}

Averages and percentages were used to compute the participation of male and female labor in postharvest activities. Information about post-harvest activities was obtained from the farmers during following operations: (i) harvesting, (ii) threshing, (iii) parboiling, (iv) drying, and (v) storage.

\section{Decision making index}

Following the methodology used by Bose et al. (2009), ñ̂Women decision making Indexò (DMI) has been constructed in this article in consideration of women participation in household decision making process in carrying out $\mathrm{PH}$ activities. We assigned the lowest value $(=0)$ when the decision is taken by male alone, in this case women being lowest ñempoweredò. When decision is taken 
jointly by husband/male and female we assigned value $=1$. The highest value $(=2)$ is assigned when decision is taken by female alone, that is, when women are most ñempoweredò.

The following formula was used for DMI

DMI $=\frac{\times 0+\times 2+\times 1}{}$

Where,

$\mathrm{F}=$ Female Female decision $=2$

$\mathrm{M}=$ Male Male decision $=0$

$\mathrm{B}=$ Both Both $=1$

The rating values of decision makers have been assigned according to the weight in favor of the female/wife for all the activities. Again, to assess the individual decision making status and position of all women respondents, two randomly defined ranges are arranged as given below:

Not decision maker DMI Ò1

Decision maker DMI > 1

\section{Weighted average method}

The weighted average formula was used to calculate the average value of a particular set of numbers with different levels of relevance. The relevance of each number is called its weight. The weights should be represented as a percentage of the total relevancy. Therefore, all weights should be equal to $100 \%$, or 1 . The most common formula used to determine an average is the arithmetic mean formula. This formula adds all of the numbers and divides by the amount of numbers. The formula of weighted average = $\mathrm{w}_{1} \mathrm{x}_{1}+\mathrm{w}_{2} \mathrm{x}_{2}+\mathrm{w}_{3} \mathrm{x}_{3}+$ é é $+\mathrm{w}_{\mathrm{n}} \mathrm{x}_{\mathrm{n}}$

\section{Results and Discussion}

Gender involvement in agricultural activities

From 1995-96 the size of adult labor force (15 years and above) has increased from 36.1 million to 40.7 million at the end of the year 1999-2000 with growth rate of $3.2 \%$. However, the growth of female labor force is increasing day by day. During the above period the growth of female labor force was $14.4 \%$ put side by side with male $1.2 \%$. From the Labor Force Surveys (LFS) in between 20022003, 2005-2006 and 2010 (Table1) the same trend was observed.

Table 1. Annual average labor force growth rate over time by gender: Bangladesh

\begin{tabular}{|l|l|l|l|}
\hline Periods & $\begin{array}{l}\text { Both } \\
\text { sexes }\end{array}$ & Male & Female \\
\hline $1995-96$ to 1999-2000 & 3.2 & 1.2 & 14.4 \\
\hline $\begin{array}{l}1999-2000 \text { to 2002- } \\
2003\end{array}$ & 4.4 & 3.8 & 6.5 \\
\hline $\begin{array}{l}2002-2003 \text { to 2005- } \\
2006\end{array}$ & 2.21 & 1.23 & 5.45 \\
\hline 2005-06 to 2010 & 3.39 & 1.40 & 8.69 \\
\hline
\end{tabular} $\begin{aligned} & \text { Source: Labor Force Survey (LFS) 1999-2000, 2002- } \\
& \text { 2003, 2005-2006 and 2010 }\end{aligned}$

Again, participation of female labor in agriculture compared to male also increased over time. With an increase of $21.53 \%$ from $1999-2000$ to 2005 2006 adult labor force has increased from 39.0 million to 47.4 million (Table 2).

Table 2. Sector wise gender labor contribution

\begin{tabular}{|l|l|c|c|c|}
\hline Year & Sector & Male & Female & Total \\
\hline \multirow{3}{*}{$\begin{array}{l}\text { 2999- } \\
\text { 2000 }\end{array}$} & Agriculture & 16.2 & 3.8 & 20 \\
\cline { 2 - 5 } & Non-Agriculture & 14.9 & 4.1 & 19 \\
\cline { 2 - 5 } & Total & 31.1 & 7.9 & 39 \\
\hline \multirow{2}{*}{$2002-$} & Agriculture & 17.2 & 5.8 & 22.9 \\
\cline { 2 - 5 } & Non-Agriculture & 17.3 & 4.1 & 21.3 \\
\cline { 2 - 5 } & Total & 34.5 & 9.8 & 44.3 \\
\hline \multirow{2}{*}{$2005-$} & Agriculture & 15.1 & 7.7 & 22.8 \\
\cline { 2 - 5 } & Non-Agriculture & 21 & 3.6 & 24.6 \\
\cline { 2 - 5 } & Total & 36.1 & 11.3 & 47.4 \\
\hline \multirow{3}{*}{2010} & Agriculture & 15.2 & 10.50 & 25.72 \\
\cline { 2 - 5 } & Non-Agriculture & 23 & 5.7 & 28.70 \\
\cline { 2 - 5 } & Total & 38.2 & 16.20 & 54.42 \\
\hline
\end{tabular}

Source: Labor Force Survey (LFS) 1999-2000, 20022003, 2005-2006, and 2010

While female labor force has increased by $43 \%$, compare to $16 \%$ of men. Particularly, in agricultural sector the trend of absolute decrease in male labor force had been seen. With a decrease by $7 \%$ agricultural male labor force decreased from 16.2 million to 15.1 million from the year 19992000 to 2005-2006. On the other hand, during the same period, female labor force in agriculture has increased from 3.8 million to 10.5 million. Comparative positions of men and women participation in agriculture in the year 2010 can be seen clearly from Table 2 .

Participation of male labor force in non-agricultural activities, on the other hand, has increased from 14.9 million to 23.0 million from $1999-2000$ to 2010. Changing the trend of participation of male laborers from agriculture to non-farm activities has created a tremendous labor shortage in the agricultural sector of Bangladesh. The findings of the researcher also indicate that, in the non-farm sector the opportunities for employment of the male labor force has increased over time while for female labor force it has decreased to some extent. For male labor force the percentage of adult participation in agriculture has decreased from $51.9 \%$, to $41.4 \%$ and $31.9 \%$ according to the LFS of 1999-2000, 2002-2003 and 2005-2006, respectively. On the other hand percentages of women in agriculture increased gradually from $48.1 \%$ to $68.1 \%$ according to LFS of $1999-2000$ and 2005-2006, respectively showed in Table 3. But in 2010 male labor force increased and female labors decreased compare to previous year of studies. 
Table 3. Percentage contribution of gender labor in agricultural sector: Bangladesh

\begin{tabular}{|c|c|c|}
\hline Year & Male & Female \\
\hline $1990-2000$ & 51.9 & 48.1 \\
\hline $2002-2003$ & 41.4 & 58.6 \\
\hline $2005-2006$ & 31.9 & 68.1 \\
\hline 2010 & 39.8 & 64.8 \\
\hline
\end{tabular}

Source: Labor Force Survey (LFS) 1999-2000, 20022003, 2005-2006, and 2010

Gender contribution to post harvest activities At the time of harvesting male labor spent more time to harvest than female and there is a considerable participation of hired labor. But at Khulna, women participation at harvesting is noticeable, this is because in the Hindu colonized area women go outside home of doing harvesting along with their male family member which is restricted at Muslim areas. Total time allocation for harvesting per hector is $\mathbf{5 3 2}$ hour for Jessore, 479 hour for Khulna and 389 hour for Rangpur as harvesting is done manually. Farmers always try to harvest in a short possible time being afraid of different natural calamities and also over ripening, for which they have to hire more labor to finish, which in turn increases their cost of production. There are not so differences in threshing between Jessore (215 hour) and Khulna (223 hour) as mechanized threshing is practicing there because of its widely availability. Male participants of Jessore on threshing are much higher than female as technology is mainly handled by males. But at Khulna females involved more on threshing although different mechanization is observed there. On the other hand at Rangpur where threshing is manually done takes more time (314 hour) than others, as threshers are not very popular here at the time of Aman season because of its small-scale production. Here it is noticed that generally males do manual threshing than females, as it requires heavy working ability which sometime is not affordable by female.

Table 4. Time (hour) allocation for post-harvest activities per hector for Aman season

\begin{tabular}{|c|c|c|c|c|c|c|c|c|c|c|}
\hline \multirow[t]{2}{*}{ Activities } & \multicolumn{3}{|c|}{ Jessore } & \multicolumn{3}{|c|}{ Khulna } & \multicolumn{3}{|c|}{ Rangpur } & \multirow{2}{*}{$\begin{array}{c}\text { Total } \\
\text { Avg. } \\
\text { time ha }\end{array}$} \\
\hline & Male & Female & Total & Male & Female & Total & Male & Female & Total & \\
\hline Harvesting & 350 & 182 & 532 & 262 & 217 & 479 & 226 & 163 & 389 & 467 \\
\hline Threshing & 123 & 92 & 215 & 107 & 116 & 223 & 185 & 129 & 314 & 251 \\
\hline Parboiling & 10 & 54 & 64 & 16 & 28 & 44 & 2 & 11 & 13 & 40 \\
\hline Drying & 196 & 411 & 607 & 145 & 181 & 326 & 57 & 112 & 169 & 367 \\
\hline Storage & 21 & 35 & 56 & 24 & 28 & 52 & 19 & 15 & 34 & 47 \\
\hline Total & 700 & 774 & 1474 & 554 & 569 & 1123 & 490 & 431 & 921 & 1173 \\
\hline $\begin{array}{c}\text { Avg. Labor } \\
\text { (no. of labor } \\
\mathrm{ha}^{-1} \text { ) }\end{array}$ & 88 & 97 & 185 & 69 & 71 & 140 & 61 & 53 & 114 & 146 \\
\hline $\begin{array}{l}\text { Avg. wage } \\
\text { (Taka) }\end{array}$ & 204 & 151 & & 284 & 180 & & 223 & 88.9 & & \\
\hline
\end{tabular}

The above Table 4 shows the time allocation at different post harvest activities of Aman rice per ha of land. But almost all the females in the study areas who take the risk of doing hand threshing make them suffer from different pain related diseases. So persuading farmers for using threshers by personal / community purchasing or the Govt. subsidy should be a great solution to them which in turn reduces labor cost as well as human work stress. Parboiling is done mainly by the females of the family; sometimes males help them in carry out such activities which is not so negligible. The overall average time allocation for parboiling is 40 hour per hector.

In case of drying the female participation is higher than men as almost all the respondent farmers use sun drying or solar drying at their homestead areas or roads adjacent to their homes. Manual drying which takes long time duration to cover, women have highest involvement along with their homestead chores. So to remove this type of drudgery different type of dryer (i.e. collapsible dryer, flatbed dryer) has been introduced only by IRRI, which took only few hours to complete drying and also keeps proper moisture. Farmers of the study areas especially women very interested with these dryers but having a large costing figure most of them lagged behind.

Women spent more time for storage activities than men and total time allocation for storage is 47 hour. Average labor required to conduct post-harvest activities per household per ha is lower at Rangpur 114 person as the labor scarcity is severe due to migration. As Because of labor is very cheap at Rangpur compare to other region migration to south from north of Bengal prevails. The wage rate of hired male labor is higher at Khulna 284 Tk. followed by Jessore $204 \mathrm{Tk}$. and Rangpur $223 \mathrm{Tk}$. Women wage rate is apparently very lower at all the region. The burden of almost all postharvestactivities is lies on women and technology reduces the workload by saving time. Thatôs why 
technology intervention should be widely exposed to the farmers to understand its importance and value, how much it is important for women health.

Women empowerment in decision making process Womenôs participation in decision making process indicates their level of social development. The economic independence of women and their share of contribution to the family are considered major factors, which influence the participation of women in family decision making process. However, there are other social factors that influence the participation of women in household decision making. To assess the extent of participation of women in household decision making process on different improved post-harvest related activities can be seen from the Table 5 .

Table 5. DMI on the average responses of the respondent on different post harvest activities

\begin{tabular}{|c|c|c|c|c|c|c|c|}
\hline \multirow[b]{2}{*}{ Activities } & \multirow[b]{2}{*}{ Respondent } & \multicolumn{2}{|c|}{ Jessore } & \multicolumn{2}{|c|}{ Khulna } & \multicolumn{2}{|c|}{ Rangpur } \\
\hline & & $\begin{array}{l}\text { Decision of } \\
\text { adopting } \\
\text { technology }\end{array}$ & $\begin{array}{c}\text { Technology } \\
\text { used by }\end{array}$ & $\begin{array}{l}\text { Decision of } \\
\text { adopting } \\
\text { technology }\end{array}$ & $\begin{array}{c}\text { Technology } \\
\text { used by }\end{array}$ & $\begin{array}{l}\text { Decision of } \\
\text { adopting } \\
\text { technology }\end{array}$ & $\begin{array}{l}\text { Technology } \\
\text { used by }\end{array}$ \\
\hline \multirow{4}{*}{ Threshing } & Male & 22 & 20 & 21 & 22 & & 1 \\
\hline & Female & 5 & 3 & 2 & 3 & & \\
\hline & Both & 37 & 40 & 20 & 18 & 4 & 3 \\
\hline & DMI & 0.73 & 0.73 & 0.56 & 0.56 & 1 & 0.75 \\
\hline \multirow{4}{*}{ Storage } & Male & 9 & 5 & 10 & 5 & 1 & \\
\hline & Female & 5 & 4 & 2 & 3 & 2 & \\
\hline & Both & 37 & 41 & 22 & 26 & 7 & 9 \\
\hline & DMI & 0.92 & 0.98 & 0.76 & 0.95 & 1.1 & 1 \\
\hline
\end{tabular}

Decision making status: Not decision maker if DMI $\leq 1$ and decision maker if DMI $>1$

To assess the extent of participation of women in household decision making process on different improved post-harvest related activities can be seen from above Table. The degree of participation has been assessed through asking question to the respondents whether the decision is taken by male alone or male and female jointly or female alone with respect to each of the activities as presented in the Table. According to weight in favor of women rating values of decision makers have been assigned (i.e., $0=$ decision is taken by male alone, $1=$ decision is taken jointly by male and female and $2=$ decision is taken by female alone). Finally, decision making Index (DMI) has been estimated following the methods as described in details in the Methodology. The findings showed that respondents used or adopt technology only in two cases (threshing and storage). Almost in two cases Decision is taken jointly by male and female. That means the trends of taking decision mainly by males are changing, now femalesô decision on households are also expected. The research found that as joint decision take place but the ultimate decision is taken by the male. We see that only at Rangpur region females are decision maker in both cases of adopting technology and technology used in case of storage. Findings showed that the value of the Decision making index for women is generally low, indicating that women are very seldom given the opportunities to implement their ideas for execution.

\section{Post-harvest related problems and reduction from} farmer perception

Farmers suggested a number of measures towards reducing harvest and post- harvest losses of rice. They suggested various measures such as timely cutting and carefully handling with efficient harvest machines. They suggested threshing rice on protected paved floor and collecting rice panicles only for reducing carrying losses. Table 6 shows different suggestions with rank to reduce postharvest loss from farmersôpoint of view. To reduce storage losses they suggested training and capacity building and awareness creation and also asked for credit facilities to set up durable and functional storage structure or containers. They suggested the need for implementing definite intervention policy for reducing marketing loss and offsetting the deception in weight and market price.

Harvesting should be done at proper way with carefulness about natural disaster will some extent reduce harvesting loss is suggested by most of the respondents. Medicine using is very important for the prevention from grain shedding. In order to reduce threshing loss concrete floor is the first requirements. Shifting from the manual to the proven efficient mechanical method of threshing will greatly reduce losses. Pedal-operated threshers have been very popular because of their portability and affordable costs, especially if made locally. Careful during threshing from domestic animals are also very important.

The reduction of field losses in harvesting and threshing can increase the profits of the small holder. To reduce parboiling loss overall carefulness about parboiling is required. At the time of drying farmers use poly sheet for easily collection of grains. Keeping away birds by using net is also very effective for wastage. The place used for drying should be cleaned around and sometimes it should be wrapped by cow dung 
instead of using poly sheet is an ongoing traditional practice. At the time of storage farmers should be careful about the cleaning of the store place. Proper drying is the utmost requirements of seed for expecting good storage. Technical knowledge of storing seed like using IRRI super bag, Margo leaf, keeping bag far from the edge of the store room (above the floor) are effective for keeping away insects.

Table 6. Farmersôsuggestion of reducing post-harvest losses

\begin{tabular}{|c|c|c|c|c|c|c|c|c|c|}
\hline \multicolumn{10}{|c|}{ Farmers suggestion in weighted average method } \\
\hline \multirow{2}{*}{ Harvesting } & Suggestion & Jessore & Rank & Khulna & Rank & Rangpur & Rank & Total & Rank \\
\hline & Careful about natural disaster & 1.14 & 3 & 6.86 & 1 & 1.14 & 3 & 9.14 & 2 \\
\hline \multirow{2}{*}{ Threshing } & $\begin{array}{l}\text { Paved floor used during } \\
\text { threshing }\end{array}$ & 5.62 & 2 & 5.05 & 2 & 4.10 & 1 & 14.76 & 1 \\
\hline & Technology required & 8.00 & 1 & 3.43 & 3 & 1.43 & 2 & 12.86 & 2 \\
\hline \multirow{3}{*}{ Parboiling } & Large pot required & 0.86 & 3 & 3.71 & 1 & 6.86 & 2 & 11.43 & 1 \\
\hline & Use enough water & 1.71 & 2 & 0.76 & 3 & 8.19 & 1 & 10.67 & 2 \\
\hline & Avoid over boiling & 3.86 & 1 & 2.43 & 2 & 4.29 & 3 & 10.57 & 3 \\
\hline \multirow{3}{*}{ Drying } & Keeping away birds \& poultry & 3.62 & 1 & 5.05 & 1 & 4.67 & 3 & 13.33 & 1 \\
\hline & Polythene/plastic sheet used & 0.71 & 3 & 2.14 & 3 & 9.52 & 1 & 12.38 & 3 \\
\hline & Clean around the drying floor & 2.29 & 2 & 4.57 & 2 & 5.71 & 2 & 12.57 & 2 \\
\hline \multirow[t]{2}{*}{ Seed storage } & Well drying & 2.14 & 2 & 2.14 & 2 & 7.86 & 2 & 12.14 & 2 \\
\hline & Well cleaned store room & 1.14 & 3 & 1.14 & 3 & 8.29 & 1 & 10.57 & 3 \\
\hline
\end{tabular}

At harvesting, parboiling and drying respondents does not give any improved solutions to PH loss as most all of them are not familiar with mechanized harvesting, parboiling and drying. In post-harvest activities the quality of the harvested crop, the degree of losses incurred and the efficiency of the operations and hence, overall costs are affected by factors related to the weather, the way of handling and the technology used. So to earn maximum profit and reducing loss farmers have to be conscious about post-harvest handling very carefully.

\section{Conclusions}

Women could achieve much more skill in agriculture sector if policy makers could provide a conductive environment for their effective participation along with men in the relevant activities. More support to women in income generating activities (IGAs) through agro-based activities should be an important part of the governmentôs strategic plan. Establishment of agrobased industries must be linked with incentives to involve more women folk from the rural areas as well as men folk. Otherwise a great portion of the

\section{References}

Bose, M. L.; Ahmad, A. and Hossain, M. 2009. The Role of Gender in Economic Activities with Special Reference to Womenô Participation and Empowerment in Rural Bangladesh. Gender, Technology and Development, 13(1). population will remain under- or un-utilized by not being mainstreamed in rural development. Moreover, year-round supply of processed food items, supply of nutritious food, value addition to agricultural products and enhanced family income cannot be attained if the rural women do not have access to necessary scope to demonstrate their contribution in PHAs as female contribution in Agriculture especially in PHAs increasing day by day. This is crystal clear from the above discussion; women play an indispensable role after the harvesting of the riceproduction for post-harvesting processes/activities as most of the rural men become sluggish when they bring their harvest in home. These all post-harvest processes/activities are in addition to their usual daily domestic routine work.Men and women participated at various levels in the rice-based $\mathrm{PH}$ processes and the research shows women spent more time (591 hours) than men (581 hours). Massive training and other supportive measures are required to scale up capacity strengthening of women in conducting PHAs of rice for food security at household and national levels.

ICAR (Economic Contribution of women in Bangladesh, Indian Council of Agricultural Research). New Delhi (2009-2012).

FAO (Food and Agriculture Organization) 2003. Rural Women: Key to Food Security, Gender and Population Division. FAO, Rome. 
Government of the Peopleôs Republic of Bangladesh 2002. Report of the labor force survey Bangladesh 1999-2000, Bangladesh bureau of Statistics, Planning Division, Ministry of Planning.

Government of the Peopleôs Republic of Bangladesh 2004. Report of the laborforce survey Bangladesh 2002-2003, Bangladesh bureau of Statistics, Planning Division, Ministry of Planning.

Government of the Peopleôs Republic of Bangladesh 2008. Report of the labor force survey Bangladesh 2005-2006, Bangladesh bureau of Statistics, Planning Division, Ministry of Planning.
Government of the Peopleôs Republic of Bangladesh 2011. Report of the labor force survey Bangladesh 2010, Bangladesh bureau of Statistics, Planning Division, Ministry of Planning.

Hossain, M. and Bayes, A. 2009. Rural Economy and Livelihoods: Insights from Bangladesh. A. H. Developing Publishing House, Dhaka, Bangladesh.

Hossain, M. and Jaim, W. M. H. 2011. Womenôs participation in agriculture in Bangladesh 19882008: changes and determinants. Paper presented in the pre-conference at Asian Society of Agricultural Economists (ASAE) International Conference Hanoi, Vietnam, October 12, 2011.

Rahman, M. Z. and Begum, A. 2009. Capacity Strengthening of Rural Women in Carrying out Post Harvest Activities of Vegetables and Fruits towards Food Security. National Food Policy Capacity Strengthening Programme. 